\title{
Some Remarks on the Ambiguous Portrayal of Olaf Haraldsson in Snorri Sturluson's Narrative
}

Olaf Haraldsson got down in history as a missionary king who by efforts to converse his countrymen became one of the father-founders and a patron saint of Christian Norway. His accomplishments reached down inside the collective memory of Scandinavian societies, making him Rex Perpetuus Norwegie (the "Eternal King of Norway") and the most distinctive figure among the Norwegian kings whose rules have been perpetuated in sagas. However, Olaf Haraldsson is portrayed as a warlike, strict ruler, severe in inflicting punishments - an image that is far from the ideal of a mild, merciful saintly king established in the European hagiographical tradition. ${ }^{1}$ This contradictory nature of the holy king seems to be reflected by the words written down in Historia Norwegie that call him beatissimus tyrannus — "the most blessed tyrant" or "the most blessed Viking." Regardless of the actual meaning of tyrannus, both words (a tyrant and a Viking) seem to convey a rather pejorative sense - the first referring to Olaf's tough-minded rules (with all its consequences, including his downfall and martyr's death), the second to his Viking raids or his warlike character. None of these seem to fit the virtues of a saintly king.

${ }^{1}$ See (with referential literature) G. PAC: Problem świętości władców we wczesnym i petnym średniowieczu - przypadek polski na tle europejskim. "Historia Slavorum Occidentis" 2016, No. 2 (11), pp. 110-115.

${ }^{2}$ Historia Norwegie. Eds. I. Ekrem, P. Fisher, L.B. Mortensen. Copenhagen 2003, e-book 2006, c. 18 (including commentary on p. 151); the latter translation seems to be more accurate considering the context. 
In this regard, a passage from the Harald Sigurðarson's Saga in Heimskringla appears to be particularly meaningful. In this fragment, Snorri Sturluson the author of the largest saga devoted to Olaf Haraldsson (in a separate version and in a version embedded in Heimskringla) — presents a comparison of Olaf and his half-brother, Harald Sigurðarson, made by Halldórr Brynjólfsson, ${ }^{3}$ a figure that, according to Heimskringla, knew Olaf and Harald directly. While listing positive features of both rulers, Halldórr does not hesitate to mention also the negative ones. He says that the kings were:

[...] ágjarnir til fjár ok ríkis, ríklyndir, ekki albýðligir, stjórnsamir ok refsingasamir. Óláfr konungr braut landsfólk til kristni ok réttra siða, en refsaði grimliga peim, er daufheyrðusk við. Polðu landshǫfðingjar honum eigi réttdœmi ok jafndœmi ok reistu her í móti honum ok felldu hann á eigu sinni sjálfs. Varð hann fyrir pat heilagr. En Haraldr herjaði til frægðar sér ok ríkis ok braut allt fólk undir sik, pat er hann mátti. ${ }^{4}$

Olaf Haraldsson is presented in a little better light than his half-brother, but the given summary of his rules clearly departs from the ideal of a noble and holy king. Although he is a just ruler led by the just cause, he is also portrayed as a tyrant, unfriendly to his own people, greedy for wealth and power, who, by his deeds, caused a rebellion and his own downfall. In this way Snorri departs from the laudatory or even neutral tone, and in this departure he seems to express his own opinion - or the opinion he shares — on Olaf Haraldsson's rules. Studying this passage, Carl Phelpstead points to Jónas Kristjánsson's suggestion $^{5}$ that Snorri put these words into Halldórr's mouth in order to avoid consequences of this kind of a judgement. Also — what is meaningful Snorri underscores that Halldórr was "vitr maðr ok hǫfðingi mikill” ("a wise man and a great chieftain").

Carl Phelpstead's research constitutes a valuable contribution to the studies on Olaf Haraldsson's image in the Old Norse tradition, demonstrating the way it functions in Snorri's narrative. The study presented in this article is somewhat

${ }^{3}$ SNORRI Sturluson: Heimskringla. Ed. BJARni Aðalbjarnarson. Vols I-III. Reykjavík 2002 (hereinafter ÍF 26-28), ÍF 28, pp. 200-201; cf. C. Phelpstead: Holy Vikings: Saints' Lives in the Old Icelandic Kings' Sagas. Tempe 2007, pp. 118-119.

4 " [...] ambitious for wealth and power, imperious, not in sympathy with ordinary people, natural rulers and stern in punishment. King Óláfr forced the people of the country to Christianity and right conduct, and harshly punished those that turned a deaf ear. The leaders of the land would not put up with his just and fair judgments and rose against him here and killed him on his own territory. As a result he became a saint. But Haraldr fought for fame and power and forced all the people to submit to him, as far as he could." English translation by A. Finlay and A. Faulkes (SnORRI Sturluson: Heimskringla. Transl. by A. Finlay, A. FaulKes. Vols II-III. London 2015-2016 (hereinafter Heimskringla II-III), III, p. 121).

5 C. Phelpstead: Holy Vikings..., p. 119; Jónas Kristjánsson: Eddas and Sagas. Iceland's Medieval Literature. Transl. by P. Foote. $2^{\text {nd }}$ edition. Reykjavík 1992, p. 169. 
linked with that research, paying attention to some points of the narrative i.e. Olaf's childhood and appearance - that in a slightly more implicit way strengthen Snorri's contradictory portrayal of the holy king. However, as these devices used by Snorri are also found in the Legendary Saga, they seem to express an ambivalent attitude towards Olaf Haraldsson that functioned throughout generations after his death.

According to the tradition, in the beginning Olaf was being brought up in the estate of his grandfather Guðbrandr kúla, but later on he and his mother, Ásta Guðbrandsdóttir, moved to the farm of his stepfather, Sigurðr sýr a great-grandson of Harald Fairhair, as the tradition holds. ${ }^{6}$ Olaf is portrayed as a misbehaving child. In the Legendary Saga there is an anecdote stating that one day little Olaf found a sword in a chest. The sword used to belong to his real father, Harald grenske, and it was meant to be Olaf's when he grew up. However, Olaf did not want to wait for that moment. In the evening Sigurðr sýr saw Olaf playing with the sword. As he was concerned, he reprimanded Olaf and criticised his mother since she had allowed that. He asked Olaf to give the sword back twice, but he did not want to obey. The third time round, Olaf said: "oc æigi fær pu pat af mer onauðgum, oc vera kann pat, at ek have valld til at væriazt" ("without forcing me you won't get it, and it may be that I have enough power to defend myself"), after which he pointed the blade at his stepfather. Then Sigurðr abandoned the attempts of taking the sword away. $^{7}$

Another time, as the Legendary Saga and Heimskringla state, Sigurðr asked 10-year-old Olaf to saddle a horse for him, as there was nobody else at the farm. ${ }^{8}$ Olaf got down to work; however, he saddled a goat. When Sigurðr arrived and saw it, he said:

Auðsætt er, at pú munt vilja af hǫndum ráða kvaðningar mínar. Mun móður pinni pat pykkja sœmiligt, at ek hafa engar kvaðningar við pik, pær er pér sé í móti skapi. Er pat auðsætt, at vit munum ekki vera skaplíkir. Muntu vera miklu skapstœrri en ek em. ${ }^{9}$

${ }^{6}$ Historia Norwegie..., c. 15; ÍF 26, p. 310; Olafs saga hins helga. Die „Legendarische Saga" über Olaf den Heiligen. Eds. A. HeInRICHS et al. Heidelberg 1982 (hereinafter LS), c. 8; Ágrip af Nóregskonungasogum. A Twelfth-Century Synoptic History of the Kings of Norway. Ed. M.J. DRISCOLL. $2^{\text {nd }}$ edition. London 2008, c. 23.

7 LS, c. 8.

8 According to Legendary Saga (c. 8), Sigurðr would often ask Olaf to do that, and only this source informs us about Olaf's age at that time.

9 "It is obvious that you are deliberately frustrating my orders. No doubt your mother thinks it proper that I should make no demands on you that are not to your liking. It is obvious that we are not both going to turn out to have the same disposition. You are going to be much more arrogant than I am.” ÍF 27, pp. 3-4; English translation by Finlay and Faulkes (Heimskringla II, p. 3); cf. LS, c. 8. 
These words did not affect Olaf, who, not saying much, laughed at his stepfather and went away.

Both anecdotes build an image of Ásta as a mother lenient towards her son much more lenient than Sigurðr, but the stepfather's attitude did not concern Olaf at all. The future saint is presented as an ill-behaved, dismissive child, who was especially disrespectful towards his stepfather. To some extent this image seems to reflect a motif known from other sagas. Ármann Jakobsson draws attention to the characters of naughty, sinister, or evil-doing children that can be found in some family sagas - e.g. little Hallgerðr (Njáls saga), whose girlish beauty and "thievish" eyes foreshadow the evil which she will render in the future, or Egill Skalla-Grímsson (Egils Saga), a child having extraordinary abilities, yet whose egoism, uncontrollable aggression, disobedience towards his father, and evil rendered already in his childhood (killing a playmate who had humiliated him) constitute the attitude which he will present in the adult life. ${ }^{10}$

Unfavourable light shed on Hallgerðr and Egill in their childhood seems to be some sort of announcement of the future events resulting from the nature of their characters. Proleptic threads - this time connected with childhood of rulers, and rather not so sinister - can also be found in kings' sagas. In the saga devoted to Olaf Haraldsson, Snorri presents anecdotes emphasising tough character and warlike predilections of 3-year-old Harald Sigurðarson, who in contrast to his brothers - building huge farms for fun - plays with little pieces of wood pretending to be warships; while Olaf, for some sort of a test, throws him a grim look, Harald does not fear, and when his hair has been pulled, he avenges himself by pulling the king's moustache. Olaf then says in response: "Hefnisamr muntu síðar, frændi" ("You will be vengeful later on, kinsman"). ${ }^{11}$ Morkinskinna, on the other hand, presents an episode from the story of Olaf Haraldsson's underage son, Magnus the Good, who, being humiliated by a retainer of his fosterer, Yaroslav the Wise, exacts deadly revenge. Magnus's misdeed, however, does not cause Rus' prince's indignation; on the contrary, Yaroslav calls it a "kingly deed" ("konungligt verk") and decides to compensate for the killing to prevent further problems. ${ }^{12}$ As it is held in the tradition, underage Olaf Tryggvason also did not hesitate to kill a man. In the saga devoted to him, Oddr Snorrason informs us that 9-year-old Olaf killed, or rather executed, a man who had killed his stepfather, which, taking Olaf's young age into account, was considered a great deed. ${ }^{13}$

10 Ármann Jakobsson: Troublesome Children in the Sagas of Icelanders. "Saga-Book" 2003, Vol. 27, pp. 10-16.

${ }^{11}$ ÍF 27, pp. 107-108; English translation by Finlay and Faulkes (Heimskringla II, p. 68).

${ }^{12}$ Morkinskinna. Eds. Ármann Jakobsson, DóRĐur InGi Guðjónsson. Vol. I. Reykjavík 2011, pp. 5-6.

${ }_{13}$ OdDr Snorrason: Saga Óláfs Tryggvasonar. Ed. Finnur Jónsson. København 1932, p. 26. 
As far as the last two examples are concerned, the anticipative character of the message is not as vivid as in the previous ones; however, the quoted events emphasise personality traits which will accompany Magnus the Good's and Olaf Tryggvason's actions in their future lives. Both figures - similarly to Harald Sigurðarson - are not presented in a bad light since their actions seem to be somewhat justified, indicative of advantages of their personalities, not the result of their bad nature as in the case of, e.g., Egill Skalla-Grímsson. Therefore, the episodes from Olaf Haraldsson's childhood which portray him as a child without qualities enabling him to become a noble, saintly king are thought-provoking. On the other hand, Ármann Jakobsson points to the character of Grettir Ásmundarson (Grettis saga), who as a child had a difficult disposition, was cruel and disobedient towards his father, yet in the adult life he presents a different attitude, and although he defends others against evil, he meets with contempt and misunderstanding on the part of the society. ${ }^{14}$ Nevertheless, the assumption that this kind of tragic nature of the character may in some way appear in the tradition about Olaf Haraldsson preserved in the works of Snorri or in the Legendary Saga rather remains a matter of conjecture without a broader justification - except that the future saint, who had been a naughty child before, as a king wanted to fight against evil, yet he met with the revolt.

There may be a need to look for the explanation of the anecdotes from Olaf Haraldsson's childhood in further parts of Heimskringla. According to the saga written by Snorri, when Olaf was on his way to take over the rule in Norway having ended his Viking career, he came to Vestfold, where he was received well by former acquaintances of Harald grenske. Then he headed over to the farm of Sigurðr sýr. It was Ásta who first had found out about approaching Olaf, and then she ordered to prepare the house for the warmest welcome, told everyone to take on the best clothes, and sent for Sigurðr, inviting the most important people from the neighbourhood to the feast at the same time. Sigurðr was in the fields then. Snorri portrays him as a hard-working farmer, not interested in noble clothing, but all the same very rich, of a peaceful nature, unambitious, rather quiet, and the wisest man in Norway. As far as Sigurðr's wife is concerned, Snorri says that she was "or ok ríklunduð" ("liberal and imperious"). When the messengers conveyed Ásta's words to Sigurðr, he expressed his dissatisfaction with the support she decided to give to her son as he thought that Olaf and his followers put themselves in too much danger on the part of Cnut the Great and Olaf Skotkonung. Next he attired himself finely and set out for the meeting with his stepson. On arrival, although he asked Olaf in, first he greeted him without much courtesy, not having dismounted a horse. Ásta came up to Olaf, kissed him, offered all the lands and troops she could for his service, took his hand, and led him into the living room. Later on,

14 Ármann Jakobsson: Troublesome Children..., pp. 16-19. 
some day, Olaf revealed to his parents that his intention was to retrieve Olaf Tryggvason's lands from Cnut and Olaf Skotkonung, even if it cost his life, counting on his stepfather's support at the same time. Sigurðr found Olaf's plans more impulsive than well-considered and not compliant with his (Sigurðr's) cautious nature, adding that Olaf had been "full of eagerness and irresponsibility to the full extent of his power" ("fullr af kappi ok ójafnaði í ollu pví, er pú máttir") already in his youth. He offered to give him a hand, but he insisted on being particularly careful - e.g. by asking other rulers of Oppland (whom, later on, Olaf Haraldsson will brutally subdue) for opinions - and reminded him of Olaf Tryggvason's fate. In this conversation, Ásta demonstrated much more enthusiasm about her son's plans, saying that she would sooner he became the "supreme king" ("yfirkonungr") in Norway, even if he lived no longer than Olaf Tryggvason, rather than he lived to a grand old age as a ruler not greater than Sigurðr. ${ }^{15}$

The fragment of Heimskringla concerning Olaf Haraldsson's return to the place where he grew up seems to be symbolic and quite clearly connected with anecdotes about his childhood through the description of Olaf and his parents' relationship. As far as the symbolic aspect is concerned, Snorri may refer to the evangelical parable of the prodigal son. The parable reads as follows:

A man had two sons. The younger one said to his father, "Father, give me my share of the estate." So the father divided his property between them. A few days later, the younger son gathered everything he owned and traveled to a distant country. There he wasted it all on wild living. After he had spent everything, a severe famine took place throughout that country, and he began to be in need. So he went out to work for one of the citizens of that country, who sent him into his fields to feed pigs. No one would give him anything, even though he would gladly have filled himself with the husks the pigs were eating.

Then he came to his senses and said, "How many of my father's hired men have more food than they can eat, and here I am starving to death! I will get up, go to my father, and say to him, 'Father, I have sinned against heaven and you. I don't deserve to be called your son anymore. Treat me like one of your hired men'."

So he got up and went to his father. While he was still far away, his father saw him and was filled with compassion. He ran to his son, threw his arms around him, and kissed him affectionately. Then his son said to him, "Father, I have sinned against heaven and you. I don't deserve to be called your son anymore." But the father said to his servants, "Hurry! Bring out the best robe and put it on him, and put a ring on his finger and sandals on his feet. Bring the fattened calf and kill it, and let's eat and celebrate! Because my son was dead and has come back to life. He was lost and has been found." And they began to celebrate.

15 ÍF 27, pp. 39-46; English translations by Finlay and Faulkes (Heimskringla II, pp. 25, $27-28)$. 
Now the father's older son was in the field. As he was coming back to the house, he heard music and dancing. So he called to one of the servants and asked what was happening. The servant told him, "Your brother has come home, and your father has killed the fattened calf because he got him back safely."

Then the older son became angry and wouldn't go into the house. So his father came out and began to plead with him. But he answered his father, "Listen! All these years I've worked like a slave for you. I've never disobeyed a command of yours. Yet you've never given me so much as a young goat for a feast so I could celebrate with my friends. But this son of yours spent your money on prostitutes, and when he came back, you killed the fattened calf for him!"

His father said to him, "My child, you are always with me, and everything I have is yours. But we had to celebrate and rejoice, because this brother of yours was dead and has come back to life. He was lost and has been found."16

Snorri rephrases this parable, adding a new character, the son's mother, and dropping the character of the brother unhappy about the return. Although Sigurðr reminds the parabolic father as far as his wisdom and wealth are concerned, he does not show enthusiasm about the return of his son (stepson). This role is taken over by Ásta, who orders a feast to be prepared on this occasion and kisses her son greeting him warmly. Wise Sigurðr, however, takes over the role of the prodigal son's brother - when Olaf approaches the house, Sigurðr is in the fields, and having been told the news by messengers, he does not express his delight. Olaf, on the other hand, does not return as a remorseful son, but he fierily pursues the power in the country; what is more, in a conversation with his parents, he confesses that he and his companions made a living robbing innocent people, sometimes killing them, often putting their (Olaf and his companion's) own lives and, what is meaningful, "souls" ("sálu") on the line. ${ }^{17}$ In the parable, the thread of understanding between the wise father and the son seems to be based on the youth's positive alternation, mutual understanding, and noble values. In Snorri's narrative, however, Olaf and wise Sigurðr are not related to each other at all, but there is something that makes Olaf related to Ásta, who plays the part of the evangelical father (but being imperious at the same time), namely the earthly ambition. Unlike the prodigal son, Olaf's temper from times before his Viking voyage does not change, which is emphasised quite clearly in Sigurðr's words. Snorri also refers to a motif well established in the Old Norse literature - that of an imperious, politically powerful woman, governed by low incentives. ${ }^{18}$ Thus he makes this

\footnotetext{
${ }^{16}$ Luke 15, 11-32 (scripture taken from the Holy Bible: International Standard Version).

17 ÍF 27, p. 43.

18 See Jóhanna Katrín Friðriksdóttir: Women in Old Norse Literature. Bodies, Words, and Power. New York 2013, pp. 79-87, 91—93; J. Morawiec, A. Jochyмeк: Sagi królewskie
} 
type of a woman the mother of the "non-prodigal" son - non-prodigal in her own eyes.

In Heimskringla, within a period of childhood as well as after the return to Norway, Olaf's relationship with his stepfather and mother seems to be an allegorical expression of his own nature, inconsistent with wisdom, common sense, and submissiveness, but in consonance with imperiousness and shortsighted fieriness. As it may be noticed at the beginning of this text, these are not the only passages in which Snorri implicitly expresses his opinion - or the opinion he shares - on the historical figure of Olaf Haraldsson and the nature of his rules, thus explaining the reasons of his fall. It is also worth noting that the anecdote about Olaf's childhood which Snorri incorporated into his work is included in the Legendary Saga - a slightly older source — which describes yet another aforementioned story emphasising equally negative traits of the young Olaf. In contrast to Snorri's narrative, it is more difficult to define the aim of these anecdotes in this saga as the source presents further relationship between Olaf and his stepfather in a more positive light.

At the same time, Snorri does not depart from the biographical convention, emphasising a wide range of the future king's advantages. The author of Heimskringla states that when Olaf grew up:

[...] ljósjarpr á hár, breiðleitr, ljóss ok rjóðr ì andliti, eygðr forkunnar vel, fagreygr ok snareygr, svá at ótti var at sjá ì augu honum, ef hann var reiðr. Óláfr var ìpróttamaðr mikill um marga hluti, kunni vel við boga ok syndr vel, skaut manna bezt handskoti, hagr ok sjónhannarr um smiðir allar, hvárt er hann gerði eða aðrir menn. Hann var kallaðr Óláfr digri. Var hann djarfr ok snjallr ì máli, brádgọrr at ollum proska, bæði afli ok vizku, ok hugbekkr var hann ollum frændum sìnum ok kunnmǫnnum, kappsamr ì leikum ok vildi fyrir vera ọllum ǫðrum, sem vera átti fyrir tìgnar sakir hans ok burða. ${ }^{19}$

A bit earlier, Snorri also notes that "Vitr var hann ok snimma ok orðsnjallr"20 ("He was wise and soon eloquent too"). The author of the Legendary Saga speaks highly of the young Olaf as well, saying: "svæinnenn skarulegr með

(Konungasogur). In: Sagi islandzkie. Zarys dziejów literatury staronordyckiej. Eds. J. MorAWiec, Ł. Neubauer. Warszawa 2015, pp. 89-90.

19 "[he was of] light brown hair, broad in the face, light and ruddy of complexion, with exceptionally fine, handsome and keen eyes, so that it was fearful to look into his eyes if he was angry. Óláfr was a very accomplished man in many ways, he knew well how to use a bow and was a good swimmer, most skilled with a javelin, an able craftsman with a good eye for all kinds of craftsmanship, both his own work and other people's. He was known as Óláfr digri (the Stout). He was bold and eloquent in speech, matured early in every way, both physically and mentally, beloved of all his kinsmen and acquaintances, competitive in sports, wanting to outdo everyone, as befitted his status and birth." ÍF 27, p. 4; English translation based on Heimskringla II, p. 3.

20 ÍF 27, p. 3. 
miklu manviti oc at allre atgœrvi mæir en at vætratale"21 ("a wise boy of great intelligence and capable of any faculties far above his age").

According to Snorri, Olaf was a clever and talented boy, a true ideal, which, however, contrasts with a description of his appearance. In the tradition, Olaf is quite often referred to with the byname inn digri — "the Stout" — because of his build, ${ }^{22}$ which Snorri does not avoid either. What is more, the author of Heimskringla states: "Óláfr Haraldsson, er hann óx upp, var ekki hár, meðalmaðr ok allprekligr, sterkr at afli" ("Óláfr Haraldsson, when he grew up, was not tall, a medium man and very sturdily built, physically strong"), and in another passage, also referring to Olaf's youthful years, he notes that the future king was "fríðr sýnum, meðalmaðr á vǫxt" ("handsome-looking, of middling height"). ${ }^{23}$ Thus, Snorri straightforwardly says that Olaf was rather short ${ }^{24}$ but stocky at the same time, mildly pointing out that he was fat. It does not fully suit conventional features of the distinctive figures. In contrast, in the passages describing Harald Sigurðarson's appearance, the author of Heimskringla emphasises not only his handsomeness, but also his robust build/tallness. ${ }^{25}$ A similar description may be found in case of Harald Fairhair, ${ }^{26}$ Haakon the Good, ${ }^{27}$ Olaf Tryggvason, ${ }^{28}$ or the further opponent of Olaf Haraldsson, Erlingr Skjalgson. ${ }^{29}$ Handsomeness or robust build/tallness are also qualities of many other figures (including rulers) present in Heimskringla..$^{30}$ Although handsomeness - most often described in Snorri's work by adjectives fríðr or fríðastr is also inherent to Olaf Haraldsson, it is futile to look for words distinctive for describing robust build — like mestr/meiri... (e.g. ...en allir menn), mikill, or hár - in regard to his physical appearance.

Therefore, it may be assumed that Snorri tried to depict Olaf's appearance according to the knowledge he possessed or his own imagination, whereby his complimentary words rather seem to suit medieval biographical tendency.

${ }^{21}$ LS, c. 8 .

${ }^{22}$ It is most probable that the byname inn digri refers to the real physical features of Olaf Haraldsson, but not in a negative sense, as it was used by his followers - or at least by his scald Sigvatr Pórðarson (see V. Henriksen: Hellig Olav. Oslo 1986, p. 52; J. Morawiec: Między poezja a polityką. Rozgrywki polityczne w Skandynawii XI wieku w świetle poezji ówczesnych skaldów. Katowice 2016, p. 401).

${ }_{23}$ ÍF 27, pp. 3-4; English translations by Finlay and Faulkes (Heimskringla II, p. 3).

${ }^{24}$ See also ÍF 28, p. 274.

${ }^{25}$ ÍF 27, p. 347; ÍF 28, pp. 95, 198-199; see also ÍF 28, pp. 186-187.

26 ÍF 26, pp. 94, 148.

27 ÍF 26, pp. 143, 146, 189.

${ }^{28}$ ÍF 26, pp. 231-232, 266; ÍF 27, p. 340.

29 ÍF 27, p. 29.

${ }^{30}$ See Íf 26, pp. 12, 17, 40, 81, 84, 87, 91, 146, 149, 162, 177, 204, 213, 284-285, 296, $330,346,362,365$, 372; ÍF 27, pp. 25, 37-38, 65, 113, 160, 172, 211, 236, 243, 258, 261-262, $300-302,349-350,369,375,383$; ÍF 28, pp. 36, 119, 121-122, 152, 194, 197, 203, 216, 225, $227,229-230,235,256,258,260,267,278,287,297,323,330-331,384,412$. 
However, it cannot be excluded that Snorri used the description of Olaf's appearance — similarly to the aforementioned anecdote about the king's childhood - to embed a bit deeper content into his narrative.

It is worth paying attention to the appearance of the co-ruling Magnusson brothers — Eysteinn (1103 - 1123), Sigurðr (1103 - 1130), and Olaf (11031115 ) - as it is described by Snorri. The first one is the most handsome, but of medium height, the second one is not handsome (which Snorri surprisingly clearly points out), but of large build, the third one is handsome, but not the most, tall, but slim at the same time. ${ }^{31}$ Olaf Magnusson was much younger, so the older brothers ruled on his behalf, and he died prematurely, not having played a significant role. It seems, then, that the descriptions of the truly ruling Eysteinn and Sigurðr are complementary, creating together the right image of a king. Thus Olaf Haraldsson's appearance seems to suit the ideal of a dignified ruler only partially, just like in the case of Eysteinn and Sigurðr - each of them, not being a sole king of Norway, constitutes only a fragmentary image of the ideal.

There is also another flaw of Olaf Haraldsson's appearance presented by Snorri. His broad, "light and ruddy" face is rather far - considering the convention - from finding him handsome, and, what is more, his hair is brown, like hair of the "not handsome" Sigurðr Magnusson and unlike fair hair of Eysteinn Magnusson. According to the conventional narrative of Heimskringla, beautiful hair is characterised by its fair, blond colour, whereas perfect complexion is characterised by its flawless fairness. One of the examples may be the description of king Olaf the Peaceful (1066/1069-1093):

Óláfr var maðr mikill á allan vọxt ok vel vaxinn. Pat er allra manna sọgn, at engi maðr hafi sét fegra mann eða tíguligra sýnum. Hann hafði gult hár sem silki ok fór afar vel, bjartan líkam, eygðr manna bezt $[\ldots . .32$

References to the conventional ideal may also be found in Heimskringla passages of hagiographical style. One of them tells of a dream about curls of Hálfdan the Black, Harald Fairhair's father - all distinguished by any colour, but one of them stood out with its beauty, i.e. its fairness and size ("fegro ok ljósleik ok mikilleik"). Curls, as the saga explains, symbolised Hálfdan the Black's descendants, and the most beautiful one - Olaf Haraldsson. ${ }^{33}$ In another passage, Snorri describes late Olaf Haraldsson's face, which was beautiful

31 ÍF 28, p. 256, cf. p. 260.

32 "Óláfr was a big man in every part of his growth and well shaped. Everyone used to say that no one had seen a handsomer man or one nobler in appearance. He had yellow hair like silk and it became him extremely well, a shining body, the finest of eyes [...]." ÍF 28, p. 203; English translation by Finlay and Faulkes (Heimskringla II, p. 123).

33 ÍF 26, pp. 90-91. 
and "miklu bjartara" ("much brighter") than when he was alive. ${ }^{34}$ On the other hand, the young Olaf's face was both light and ruddy. What is more, his hair was light brown. Therefore, the description of Olaf Haraldsson's appearance presented by Snorri seems to be full of meaningful contradictions. Olaf is handsome, sturdy, but not tall. Despite being handsome, he has a ruddy face and brown hair. Although the colour of his face and hair is far from the ideal, they are of light shade. It is hard to find another figure at least partially corresponding to such a combination of features in Heimskringla. ${ }^{35}$

Olaf's portrayal offered by Snorri is also divergent as far as his deeds are concerned - on the one hand, he is depicted as a valiant Viking and imperious ruler, on the other hand, as a saint who distinguished himself in history of the Norwegian Church and state. In this way, as Carl Phelpstead suggests, ${ }^{36}$ Snorri plays roles of both a historiographer, in his way pursuing the reliable image of the past, and a hagiographer, who commemorates the saint's deeds following the relevant convention. The author of Heimskringla seems to express this tendency in the description of Olaf's appearance, joining together two ways of perceiving the figure of the Eternal King of Norway, who by his actions was far from the ideal that further generations saw — at least partially — in him. In Snorri's narrative, Olaf's image, in line with hagiographical convention, gains in appearance after he sacrificed his life - he was no longer a mortal ruler with a burden of human flaws, but became the saint king of Norway for all time.

The device that Snorri uses seems, however, to be rooted deeper in the tradition. In the Legendary Saga — which is of the most hagiographical character among the sagas devoted to Olaf Haraldsson - there is a similar description of Olaf's appearance, which is an element of a comment summarising his figure:

Olafr konongr var vænn maðr oc listulegr ivirlitum, riðvaxenn oc ækci har, hærðimikill oc biartæygðr, lios oc jarpr a har oc liðaðezc væl, rauðskæggiaðr oc rioðr i anlete, rettlæitr oc ænnibræiðr oc openæygðr, limaðr væl oc litt fœttr, fraknutr oc fastæygðr, hugaðlatr oc raundriugr. Olafr var manna vitraztr oc sa, hvat bazt gængdi, ef hann lec i tome um at hyggia. En ef nokcot var braðom boret, pa var pat hætt. Olafr virði mikils kirkiur oc kænnimenn oc allan kristinn dom. Oc gœdde giauum goða menn; klædde kalna; gaf fe faðurlausum, auðræðe ækcium oc utlændum, pæim er fatœker varo; huggaðe ryggua oc studdi alla raðvanda menn bæðe i hæilræðom oc aðrum tillagum. Olafr var harðr við hærrmenn oc við hæiðingia, striðr við stulldarmenn, osvifr við osiðamenn. Hæfti hann hofðingia oc sva alla alpyðu. Hann ræfsti ransmannum hart, pæir er guðs rette raskaðe, en firir gaf litilatlega, pat er við hann var misgort.

34 ÍF 27, p. 387; Olaf's dignified appearance is emphasised in Heimskringla when he does his posthumous wonders (ÍF 28, pp. 138, 336-337, 372).

${ }_{35}$ Cf. description of Magnus the Good (ÍF 28, p. 107).

36 See C. Phelpstead: Holy Vikings..., pp. 117ff. 
Misiamn var orðromr um hans rað, pa er hann var i pema hæimi. Marger kallaðu hann riklyndan oc raðgiarnan, harðraðan oc hæiftugan, fastan oc fegiærnan, olman oc odælan, metnaðarmann oc mikilatan, oc pessa hæims hofðingia firir allz sakar. En pæir giorr vissu, kallaðu hann linan oc litilatan, huggoðan oc hœgan, milldan oc miuklatan, vitran oc vingoðan, tryggvan oc trulyndan, forsialan oc fastorðan, giaflan oc gofgan, frægian oc vællyndan, rikian oc raðvandan, goðan oc glœpvaran, stiornsaman oc væl stilltan, væl gæymin at guðs lagum oc goðra manna. Oc hava pæir rett ætlat, er sva hævir synzt, sem nu værða margar raunir a. Ef hann grunaðe pat, at nokcorom sinnum være æigi allt æit, hans fyst sialfs oc guðs forsio, pa braut hann oftlega sinn vilia, en gerðe guðs vilia. Læitaðe iamnan guðs dyrðar mæir en sinnar virðingar af alpyðu rettsynna manna. En guð lætr nu pui mæir hans dyrð birtazt, sem hann dyrkaðe hann mæir i sinu livi en litilætte sialvan sic mæir bæðe guði oc mannum. ${ }^{37}$

The description of Olaf's appearance presented in the Legendary Saga corresponds to the one used by Snorri. Moreover, it is juxtaposed with a summary of Olaf's rules - a summary that is quite ambivalent, emphasising a wide range of positive features on the one hand, and mentioning the negative judgement of his deeds on the other. This juxtaposition, which seems to be intrinsically natural, may have been accompanied by a deeper, implicit thought — Olaf's

37 "King Olaf was a handsome man and magnificent of countenance, stocky and not tall, thick-haired, and bright-eyed, with light and chestnut-coloured hair that fell in attractive curls. He had a red beard and ruddy complexion. His face had regular features, with a broad forehead and large eyes. He had good arms and legs, small feet, was freckled and firm-eyed, amiable, and very trustworthy. Olaf was the wisest of men and saw what would serve best if he took time to consider it. But if something was done quickly, it was risky. Olaf greatly esteemed churches and clergymen and all Christendom. Olaf endowed good men with gifts. He gave money to the fatherless, wealth to widows and to those foreigners who were impoverished. He comforted the grieving and supported all honest, upright people both with wise counsel and other advice. Olaf was hard against soldiers and against pagans, severe with thieves, an enemy of evil-doers. He kept in check chieftains and indeed all the populace. He punished harshly thieves, those men who disturbed God's justice, but humbly forgave what wrong was done to him.

Judgment of his conduct on this earth was mixed. Many called him imperious and ambitious, tyrannical and vengeful, stingy and greedy and savage, and an overbearing man, haughty and prideful, and a chieftain of this world in every way. But those who knew more clearly called him mild-mannered and humble, merciful and gentle, mild and meek, wise and well-liked, faithful and trustworthy, prudent and true to his word, munificent and noble, renowned and well-minded, powerful and honest, good and righteous, a wise ruler and well tempered, well heedful of the laws of God and of good men. And he has thought rightly, he who has thought thus, as there are many proofs now. If he suspected that on some occasions his own desire and God's foresight were not identical, then he frequently altered his will and did God's will. He constantly sought God's glory more than his own honour, from the popular justice of men. And may God now let his glory shine the more brightly as he glorified Him in his life and humbled himself the more before God and men." LS, c. 28; English translation by John Lindow (J. LiNDow: St Olaf and the Skalds. In: Sanctity in the North. Saints, Lives, and Cults in Medieval Scandinavia. Ed. T.A. Dubois. Toronto-Buffalo-London 2008, p. 121). 
appearance, including elements of a model ruler and elements departing from the ideal, apparently reflects ambiguity in which the remembrance of him lasted in the North. This ambiguity must have been quite a vibrant trait of the collective memory upheld by Scandinavian societies since it found its place in the semi-hagiographic Legendary Saga. By all means it is one of the works that glorifies Olaf the most, and because it is less detailed and rather chaotic full of contradictions, repetitions, scattered episodes - it may be considered as a source that reflects the state of oral tradition about Olaf more accurately than Snorri's bit younger narrative. ${ }^{38}$ Thus in order to render the ambiguity that accompanied the memory of Olaf Haraldsson, Snorri seems to use the way of its expression already established in the oral/written tradition.

Last of all, the ambiguity of Olaf's image in the Legendary Saga raises a question of the origins of the reinvented parable of the prodigal son found in Heimskringla, namely: is this reinvention Snorri's invention? The story presented in Heimskringla seems to be partial - it lacks a beginning. The biblical parable begins with the son's request for his share of the estate he made of his father in order to gain independence and live his own life. If the story found in Heimskringla had a beginning following the biblical pattern, one should expect Olaf asking Ásta - who plays the role of the biblical father - for some means allowing him to launch an expedition and live Viking's life. This episode is, however, found in the Legendary Saga, which tells that Olaf — at the age of twelve - requested a troop from Ásta saying that he wanted to go on a Viking expedition. Ásta interceded with Sigurðr on Olaf's behalf, which led Sigurðr to give his stepson two equipped ships. Then Olaf boastfully warned Sigurðr that he would come back with a large host of warriors. ${ }^{39}$

What is more, in the story presented by Snorri, Sigurðr comments on Olaf's ambitious and risky plan saying that his stepson was "full of eagerness and irresponsibility to the full extent of his power" when he was hardly more than a child. There are, however, no episodes in Heimskringla to which Sigurðr's words refer. The only episode that seems to be related to these words is the one about Olaf asking Ásta for a troop.

Hence, it seems that the Legendary Saga and Heimskringla contain separated parts of one stor $\mathrm{y}^{40}$ that had functioned in the oral/written tradition before the two sagas were written down. This allows one to assume that the reinvented parable of the prodigal son found in Heimskringla is another example of an

${ }^{38}$ See S. BAGge: Olav den Hellige som norsk konge (1015-28). "Historisk tidsskrift" 2015, Vol. 94, p. 559.

${ }^{39}$ LS, c. 9.

${ }^{40}$ It seems probable that all the aforementioned episodes - Olaf saddling a goat, Olaf finding a sword in a chest, Olaf asking Ásta for a troop, and Olaf returning from his Viking expeditions - constituted elements of one consistent story which has not remained in full, but in parts preserved in the Legendary Saga and Heimskringla. 
already known motif which Snorri decided to use in his narrative to express the ambiguity about the character and deeds of Olaf Haraldsson.

\section{References}

\section{Primary sources}

Ágrip af Nóregskonungasogum. A Twelfth-Century Synoptic History of the Kings of Norway. Ed. M.J. DRISCOLL. $2^{\text {nd }}$ edition. London 2008.

Historia Norwegie. Eds. I. Ekrem, P. Fisher, L.B. Mortensen. Copenhagen 2003, e-book 2006.

Morkinskinna. Eds. Ármann Jakobsson, PórĐur IngI Guðjónsson. Vol. I. Reykjavík 2011.

ODdR Snorrason: Saga Óláfs Tryggvasonar. Ed. Finnur Jónsson. København 1932.

Olafs saga hins helga. Die „Legendarische Saga” über Olaf den Heiligen. Eds. A. HeInRICHs et al. Heidelberg 1982.

SNORRI Sturluson: Heimskringla. Ed. BJARni Aðalbjarnarson. Vols I—III. Reykjavík 2002.

Snorri Sturluson: Heimskringla. Transl. by A. Finlay, A. Faulkes. Vols II-III. London $2015-2016$.

\section{Secondary sources}

Ármann Jakobsson: Troublesome Children in the Sagas of Icelanders. "Saga-Book" 2003, Vol. 27.

BAGge S.: Olav den Hellige som norsk konge (1015-28). "Historisk tidsskrift" 2015, Vol. 94.

HenRIKSEN V.: Hellig Olav. Oslo 1986.

Jóhanna Katrín Friðriksdóttir: Women in Old Norse Literature. Bodies, Words, and Power. New York 2013.

JónAs Kristjánsson: Eddas and Sagas. Iceland's Medieval Literature. Transl. by P. Foote. $2^{\text {nd }}$ edition. Reykjavík 1992.

Lindow J.: St Olaf and the Skalds. In: Sanctity in the North. Saints, Lives, and Cults in Medieval Scandinavia. Ed. T.A. DuBoIs. Toronto-Buffalo-London 2008.

Morawiec J., Jochymeк A.: Sagi królewskie (Konungasqgur). In: Sagi islandzkie. Zarys dziejów literatury staronordyckiej. Eds. J. Morawiec, Ł. Neubauer. Warszawa 2015.

Morawiec J.: Między poezja a polityka. Rozgrywki polityczne w Skandynawii XI wieku $w$ świetle poezji ówczesnych skaldów. Katowice 2016.

PAC G.: Problem świętości władców we wczesnym i pełnym średniowieczu - przypadek polski na tle europejskim. "Historia Slavorum Occidentis" 2016, No. 2 (11).

Phelpstead C.: Holy Vikings: Saints' Lives in the Old Icelandic Kings' Sagas. Tempe 2007. 
Maciej Lubik

\section{Pewne spostrzeżenia na temat dwuznacznego obrazu postaci Olafa Świętego w narracji Snorriego Sturlusona}

Streszczenie

Olaf Haraldsson (Święty) zapisał się w historii jako król-misjonarz, a jednocześnie jeden z ojców założycieli i święty patron chrześcijańskiej Norwegii. Jego osiągniecia utrwaliły się głęboko w pamięci zbiorowej skandynawskich społeczeństw czyniąc z niego Wiecznego Króla Norwegii (Rex Perpetuus Norwegie) i najbardziej wyróżnianą postać pośród norweskich władców, których rządy uwieczniono w sagach. Jednakże Olaf, choć święty, przedstawiany jest jako wojowniczy, twardy i surowo karcący władca - obraz, który wydaje się znacząco odbiegać od ideału łagodnego, miłosiernego i świętobliwego króla, utrwalonego w europejskiej tradycji hagiograficznej.

Tę dwojaką naturę postaci Olafa oddaje w swojej narracji Snorri Sturluson, na co już wcześniej zwracał uwagę Carl Phelpstead. Niniejsze rozważania są niejako nawiązaniem do ustaleń wspomnianego badacza, zwracając uwagę na dwa zazębiające się aspekty obrazu Olafa przedstawianego w narracji Snorriego - jego dzieciństwo i wygląd. W pierwszym wypadku Olaf jawi się jako niesforne dziecko, pozbawione szacunku do ojczyma, co koresponduje z późniejszym epizodem powrotu Olafa do Norwegii będącym parafrazą przypowieści o synu marnotrawnym. Snorri rysuje obraz młodzieńca, który w odróżnieniu od syna marnotrawnego nie zmienił swojej złej natury, a ta następnie przełożyła się na sposób sprawowanych przez niego rządów. W drugim zaś wypadku, opisując wygląd Olafa, Snorri wydaje się przedstawiać połowiczny wizerunek idealnego króla. Olaf, choć jest przystojny, o mocnej sylwetce, jasnym odcieniu twarzy i włosów, to jednak niewysoki, o rumianym licu i brązowych włosach w ten sposób uciekając od modelu wysokiego władcy o świetlistej karnacji i włosach koloru blond. Biorąc jednak pod uwagę przekaz nieco starszej Sagi Legendarnej Snorri wydaje się w obu wypadkach bazować na rozwiązaniach głębiej utrwalonych w tradycji ustnej/pisanej rozwiązaniach mających oddawać niejednoznaczność, w jakiej pamięć o Olafie funkcjonowała pośród mieszkańców Skandynawii w ciągu wielu pokoleń po jego śmierci.

Słowa klucze: Olaf Haraldsson, Snorri Sturluson, Heimskringla

Maciej Lubik

\section{Einige Bemerkungen zum doppeldeutigen Bild von Olav dem Heiligen in der Narration} von Snorri Sturluson

Zusammenfassung

Olaf Haraldsson (der Heilige) ging als König-Missionar und einer der Gründerväter und Schutzpatron des christlichen Norwegens in die Geschichte ein. Seine Errungenschaften sind im kollektiven Gedächtnis der skandinavischen Gesellschaften tief verankert und machten ihn zum Ewigen König von Norwegen (Rex Perpetuus Norwegie) und zur am meisten hervorgehobenen Figur unter den norwegischen Herrschern, deren Regierungszeit in den Sagen festgehalten wurde. Obwohl Olaf der Heilige ist, wird er allerdings als ein kriegerischer, harter und streng tadelnder Herrscher dargestellt — das ist ein Bild, das deutlich vom Ideal eines sanften, 
barmherzigen und gottesfürchtigen Königs abzuweichen scheint, das in der europäischen hagiografischen Tradition verankert ist.

Diese doppelte Natur von Olafs Charakter spiegelt sich in der Narration von Snorri Sturluson wider, worauf Carl Phelpstead bereits früher aufmerksam machte. Diese Überlegungen knüpfen gewissermaßen an die Befunde des erwähnten Forschers an, wobei zwei sich überschneidende Aspekte von Olafs Bild in der Narration von Snorri berücksichtigt werden - seine Kindheit und sein Aussehen. Im ersten Fall erscheint Olaf als ein widerspenstiges Kind, das keinen Respekt vor seinem Stiefvater hatte, was der späteren Episode von Olafs Rückkehr nach Norwegen entspricht, die eine Paraphrase des Gleichnisses vom verlorenen Sohn ist. Snorri zeichnet ein Bild von einem jungen Mann, der im Gegensatz zum verlorenen Sohn seine böse Natur nicht verändert hat, was sich in der Art und Weise niederschlug, wie er dann regierte. Im zweiten Fall stellt Snorri ein unzureichendes Bild eines idealen Königs dar, indem er das Aussehen von Olaf beschreibt. Obwohl Olaf gutaussehend und kräftig ist, sowie helle Haut und Haare hat, ist er dennoch klein, hat ein rotbackiges Gesicht und braune Haare - so weicht er von dem Modell eines großen Herrschers mit leuchtendem Teint und blonden Haaren ab. Unter Berücksichtigung der Überlieferung einer etwas älteren Legendären Saga scheint Snorri in beiden Fällen auf solchen Lösungen zu beruhen, die in der mündlichen/schriftlichen Tradition tiefer verwurzelt sind - gemeint sind Lösungen, die die Mehrdeutigkeit widerspiegeln sollten, in der die Erinnerung an Olaf unter den Bewohnern Skandinaviens in vielen Generationen nach seinem Tod funktionierte.

Schlüsselwörter: Olaf Haraldsson, Snorri Sturluson, Heimskringla 